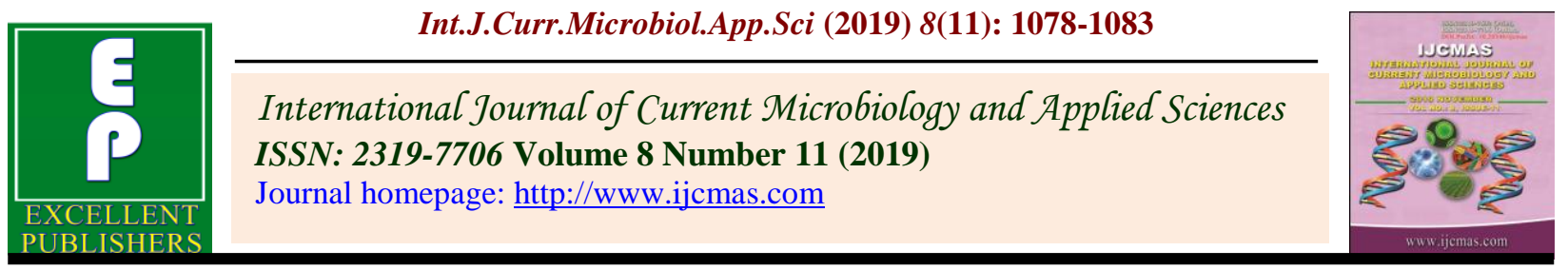

Original Research Article

https://doi.org/10.20546/ijcmas.2019.811.127

\title{
Influence of Different Sulphur Sources at Various Levels on Growth and Yield of Green Gram in Alfisol of Madurai District, Tamil Nadu, India
}

\author{
B. Jeevitha ${ }^{1 *}$, A. Rathinasamy ${ }^{2}$, P.P. Mahendran ${ }^{3}$, J. Prabhaharan ${ }^{4}$ and K. Prabakaran ${ }^{5}$ \\ ${ }^{1}$ Department of Soils and Environment, AC \& RI, Madurai - 625 104, India \\ ${ }^{2}$ Agricultural College \& Research Institute, Eachangkottai, Thanjavur-614902, India \\ ${ }^{3}$ Department of Crop Management, AC \& RI, Kudumiyanmalai-622104, India \\ ${ }^{4}$ Department of Agronomy, ${ }^{5}$ Department of Agricultural Economics, AC \& RI, \\ Madurai- 625 104, India \\ *Corresponding author
}

\section{A B S T R A C T}

\section{Keywords}

Sulphur sources, Sulphur levels, Green gram, Yield

Article Info

Accepted:

10 October 2019 Available Online: 10 November 2019
A field experiment was conducted to evaluate the influence of different sulphur sources at various levels on growth and grain yield of green gram in Alfisolof Madurai district, Tamil Nadu during kharif season in the year 2018. Four sources [Ammonium sulphate $\left(\mathrm{S}_{1}\right)$, Potassium sulphate $\left(\mathrm{S}_{2}\right)$, Magnesium sulphate $\left(\mathrm{S}_{3}\right)$ and Calcium sulphate $\left.\left(\mathrm{S}_{4}\right)\right]$ at four different levels $\left[0\left(\mathrm{~L}_{1}\right), 20\left(\mathrm{~L}_{2}\right)\right.$, $40\left(\mathrm{~L}_{3}\right), 60\left(\mathrm{~L}_{4}\right) \mathrm{kg} \mathrm{ha}^{-1}$ ] applied along with recommended source of fertilizer (RDF) were designed for the study. The experiment was replicated thrice following factorial randomized block design (FRBD). The results showed that the combined effect of RDF with calcium sulphate at the level of $40 \mathrm{~kg} \mathrm{ha}^{-1}$ had a considerable enhancement of crop growth, yield attributes and yield of green gram in Alfisol. Among the different treatment combinations, the highest and appreciable crop growth, yield attributes and maximum grain yield of $1297 \mathrm{~kg} \mathrm{ha}^{-1}$ green gram was recorded in the combined treatment, $\mathrm{L}_{3} \mathrm{~S}_{4}$ (calcium sulphate at $40 \mathrm{~kg} \mathrm{ha}^{-1}+\mathrm{RDF}$ ) and the lowest values of all parameters were observed in the control $\left(\mathrm{L}_{1}\right)$.

\section{Introduction}

Pulses are important not only for their value as human food, but also because of high protein content for livestock. It has been important component of Indian agriculture enabling the land to restore fertility by fixing atmospheric nitrogen, so as to produce reasonable yields of succeeding crops and to meet out the demand of dietary requirement regarding proteins, carbohydrates and other nutrient sources. Green gram (Vigna radiate L. Wilczek) is commonly known as 'mung' or 'mungbean', which is the most important crop throughout 
South-East Asia and particularly in the Indian sub-continent. It is the third important pulse crop which was sown over an area of 4.26 Mha in (kharif + rabi) and recorded a production of 2.01 Mt at and yield level of 472 $\mathrm{kg} / \mathrm{ha}$ (Anonymous, 2018).

It is grown mainly as kharif crop in Rajasthan, Maharashtra, Karnataka, Andhra Pradesh, Orissa, Tamil Nadu, whereas in rabi/spring it is grown in Tamil Nadu, Bihar, Orissa, Andhra Pradesh, Uttar Pradesh, West Bengal, Maharashtra and Karnataka.

In summer season it is grown in Uttar Pradesh, Madhya Pradesh, Bihar, Jharkhand and Orissa states. It is highly digestible and free from the flatulent effects unlike other pulses.

The greengram foliage left over after picking of mature pods can either be fed to livestock or it may ploughed in the field as a green manure to enrich soil with organic matter. Mungbean is a very short duration crop so it can be grown as catch crop. Sulphur enhances crop yield and produce quality of pulses. The present investigation was undertaken to study the influence of sulphur sources at different levels on growth and yield of green gram crop.

Fertilizer is an important factor which enhances the agricultural production. Sulphur is a fourth major nutrient next to nitrogen, phosphorus and potassium. The effect of Sulphur has a synergistic effect on productivity of crops (Patel et al., 2010).

Sulphur is important for production of protein, vitamins and sulphur containing amino acids viz., methionine, cystine and cysteine. Next to phosphorus, sulphur nutrition has been noticed to be key limiting factor in green gram production. Sulphur can be applied to the soil through any of the suitable sulphur sources, but the choice depends on crop, local availability, price and need for other nutrients.

\section{Materials and Methods}

Field experiment was conducted at Lalapuram village, Kalligudi block of Madurai district, Tamil Nadu during the Kharif season in the year 2018. The experimental field's soil texture was sandy loam in nature, belonged to one of the major soil order (Alfisol) in Madurai district. The $\mathrm{pH}$ of the soil was 7.25 and EC of $0.12 \mathrm{~d} \mathrm{Sm}^{-1}$. The soil was low in organic carbon with $0.19 \%$ and low in available sulphur status with a value of 4.80 $\mathrm{mg} \mathrm{kg}^{-1}$. The statistical design followed to conduct a field experiment was randomized block design with factorial concept. The treatment comprised of four different sulphur sources [Ammonium sulphate $\left(\mathrm{S}_{1}\right)$, Potassium sulphate $\left(S_{2}\right)$, Magnesium sulphate $\left(S_{3}\right)$ and Calcium sulphate $\left(\mathrm{S}_{4}\right)$ ] at four various levels [0 $\left.\left(\mathrm{L}_{1}\right), 20\left(\mathrm{~L}_{2}\right), 40\left(\mathrm{~L}_{3}\right), 60\left(\mathrm{~L}_{4}\right) \mathrm{kg} \mathrm{ha}^{-1}\right]$ with three replications. These were applied along with RDF of $25 \mathrm{~kg} \mathrm{~N}+50 \mathrm{~kg} \mathrm{P}_{2} \mathrm{O}_{5}+25 \mathrm{~kg}$ $\mathrm{K}_{2} \mathrm{O}$ for irrigated green gram. Here,the treatment $\mathrm{L}_{1}\left(0 \mathrm{~kg} \mathrm{~S} \mathrm{ha}^{-1}+\mathrm{RDF}\right)$ mean value of all parameters of green gram was taken as control and it was taken for comparison with effect of individual levels, individual sources and for treatment combinations.

\section{Results and Discussion}

The results derived from the present study are presented in the following:

\section{Effect of sulphur sources on green gram}

Different sources of sulphur application considerably increases the crop growth, yield attributes viz., plant height, number of branches per plant, number of pods per plant, number of seeds per pod, 100 seed weight and grain yield. These attributes were increased by the application of calcium sulphate than other sulphur sources. The increase in grain yield of $1018 \mathrm{~kg} \mathrm{ha}^{-1}$ and haulm yield of $1472 \mathrm{~kg} \mathrm{ha}^{-1}$ (Table 4) was observed in the experimental 
plot where calcium sulphate (gypsum) was applied as sulphur source. The increase in grain yield was about 21 per cent over control. This increase in grain yield might be due to the release of readily available $\mathrm{SO}_{4}$ in the gypsum as compared to other sources. This also might be due to mobility of sulphur for the crop growth and one more reason might be due to application of gypsum attributes a considerable improvement in the soil physicochemical properties which also helps the soil to maintain a good soil structure. These results were in conformity with the findings of Dwivedi et al., (1996).

\section{Effect of sulphur levels on green gram}

The research findings revealed that influence of sulphur levels showed a noticeable crop growth, yield attributes and yield of green gram. The increase in yield attributes was maximum when the sulphur level was applied upto $40 \mathrm{~kg} \mathrm{ha}^{-1}$. After which, the growth, yield attributes and yield decreases, (i.e)., when the sulphur level was applied upto $60 \mathrm{~kg} \mathrm{ha}^{-1}$. Application of $40 \mathrm{~kg} \mathrm{~S} \mathrm{ha}{ }^{-1}$ enhanced the growth and yield parameters appreciably. The highest grain yield of $1209 \quad \mathrm{~kg} \mathrm{ha}^{-1}$ and highest haulm yield of $1827 \mathrm{~kg} \mathrm{ha}{ }^{-1}$ was observed in the sulphur level at $40 \mathrm{~kg} \mathrm{~S} \mathrm{ha}^{-1}$. The lowest grain yield (804 $\left.\mathrm{kg} \mathrm{ha}^{-1}\right)$ and halum yield (994 $\mathrm{kg} \mathrm{ha}^{-1}$ ) was noticed in the without sulphur applied plot (Table 4). The maximum grain yield at the rate of $40 \mathrm{~kg} \mathrm{ha}^{-1}$ might be due to vital role of sulphur in maintaining the enzymetic and metabolic processes involving respiration, photosynthesis and activation of energy transformation which had reflected in highest grain yield. This was also might be due to increasing the status of available sulphur in soil and making it to reach a sufficient sulphur level which further, helps in bold seeds and filled pods which in turn enhanced the grain yield of green gram. These results were similar to the findings stated by Singh and Agarwal (1998) and Ghosh and Sarkar (2000).

\section{Effect of treatment combination on green gram}

Between the treatmental combinations, sulphur application through calcium sulphate at $40 \mathrm{~kg} \mathrm{ha}^{-1}$ showed a maximum plant height at $30 \mathrm{DAS}, 45 \mathrm{DAS}$ and at harvest were 25.5, 38.5 and $43.9 \mathrm{~cm}$ respectively (Table 1). Root length of $14.5 \mathrm{~cm}$ (Table 2), yield attributes viz., number of pods plant ${ }^{-1}$ of 17.0, number of seeds $\operatorname{pod}^{-1}$ of 10.77 and 100 seed weight of 4.00 and grain yield of $1297 \mathrm{~kg} \mathrm{ha}^{-1}$ (Table 3 and 4) were registered maximum in treatment plot where calcium sulphate at $40 \mathrm{~kg} \mathrm{ha}^{-1}$ was applied as sulphur source with recommended dose of fertilizer $\left(\mathrm{L}_{3} \mathrm{~S}_{4}\right)$ in Alfisol soil order for green gram crop which was followed by the treatment combination $\mathrm{L}_{3} \mathrm{~S}_{1}\left(40 \mathrm{~kg} \mathrm{~S} \mathrm{Sa}^{-1}\right.$ as ammonium sulphate + RDF)and root length of $7.3 \mathrm{~cm}$, yield attributes viz., number of pods plant $^{-1}$ of 8.7 , number of seeds pod ${ }^{-1}$ of 5.45 and 100 seed weight of 2.51 and grain yield of $804 \mathrm{~kg} \mathrm{ha}^{-1}$ was found minimum in sulphur unapplied plot $\left(\mathrm{L}_{1}\right)$. These results gained owing to the process of cell or tissue differentiation from somatic to reproductive meristematic activity and enlargement of floral primordial might have enhanced with the application of sulphur levels upto $40 \mathrm{~kg} \mathrm{~S}$ $\mathrm{ha}^{-1}$ resulting in more number of flowers and longer pods and higher grains yield. Similar findings were reported by Saini and Rajesh Singh (2017).

Among the different treatment combinations, the highest and appreciable crop growth, yield attributes and grain yield of green gram was recorded in the experimental plot where the calcium sulphate at $40 \mathrm{~kg} \mathrm{ha}^{-1}$ along with RDF $\left(\mathrm{L}_{3} \mathrm{~S}_{4}\right)$ was applied as sulphur source and the lowest values of those parameters were observed in the control $\left(\mathrm{L}_{1}\right)$. 
Table.1 Effect of different sulphur sources at various levels on plant height $(\mathrm{cm})$ of green gram

\begin{tabular}{|c|c|c|c|c|c|c|c|c|c|c|c|c|c|c|c|}
\hline \multirow{4}{*}{$\begin{array}{l}\text { Sulphur } \\
\text { levels }\end{array}$} & \multicolumn{15}{|c|}{ Plant height (cm) } \\
\hline & \multirow{2}{*}{\multicolumn{5}{|c|}{$\begin{array}{c}30 \text { DAS } \\
\text { Sulphur sources }\end{array}$}} & \multirow{2}{*}{\multicolumn{5}{|c|}{$\begin{array}{c}60 \text { DAS } \\
\text { Sulphur sources }\end{array}$}} & \multirow{2}{*}{\multicolumn{5}{|c|}{$\begin{array}{c}\text { At harvest } \\
\text { Sulphur sources }\end{array}$}} \\
\hline & & & & & & & & & & & & & & & \\
\hline & $\mathbf{S}_{1}$ & $\mathbf{S}_{2}$ & $\mathbf{S}_{\mathbf{3}}$ & $\mathbf{S}_{4}$ & Mean & $\mathbf{S}_{1}$ & $\mathbf{S}_{2}$ & $\mathbf{S}_{\mathbf{3}}$ & $\mathbf{S}_{4}$ & Mean & $\mathbf{S}_{1}$ & $\mathbf{S}_{2}$ & $\mathbf{S}_{3}$ & $\mathbf{S}_{4}$ & Mean \\
\hline $\mathbf{L}_{1}$ & 16.0 & 15.8 & 15.5 & 15.7 & 15.8 & 19.4 & 19.3 & 19.1 & 19.1 & 19.3 & 25.7 & 25.2 & 25.4 & 25.1 & 25.4 \\
\hline $\mathbf{L}_{2}$ & 19.7 & 19.0 & 18.4 & 20.0 & 19.3 & 30.4 & 28.7 & 27.2 & 31.8 & 29.5 & 37.5 & 35.6 & 33.7 & 39.2 & 36.5 \\
\hline $\mathbf{L}_{3}$ & 24.0 & 22.0 & 21.0 & 25.5 & 23.1 & 36.7 & 35.1 & 33.3 & 38.5 & 35.9 & 44.7 & 43.0 & 41.1 & 46.8 & 43.9 \\
\hline $\mathbf{L}_{4}$ & 17.7 & 17.2 & 16.6 & 18.0 & 17.4 & 23.9 & 22.5 & 20.9 & 25.6 & 23.2 & 30.3 & 28.7 & 26.9 & 32.0 & 29.5 \\
\hline \multirow[t]{2}{*}{ Mean } & 19.3 & 18.5 & 17.7 & 19.8 & & 27.6 & 26.4 & 25.1 & 28.8 & & 34.5 & 33.1 & 31.8 & 35.8 & \\
\hline & $\mathbf{L}$ & $\mathbf{S}$ & \multicolumn{2}{|c|}{$\mathbf{L} \times \mathbf{S}$} & & $\mathbf{L}$ & $\mathbf{S}$ & \multicolumn{2}{|c|}{ L $x$ S } & & $\mathbf{L}$ & $\mathbf{S}$ & \multicolumn{2}{|c|}{$\mathbf{L} \times \mathbf{S}$} & \\
\hline SEd & 0.20 & 0.20 & \multicolumn{2}{|c|}{0.40} & & 0.25 & 0.25 & \multicolumn{2}{|c|}{0.50} & & 0.37 & 0.37 & \multicolumn{2}{|c|}{0.74} & \\
\hline $\begin{array}{c}\text { CD } \\
(P=0.05)\end{array}$ & 0.42 & 0.42 & \multicolumn{2}{|c|}{0.83} & & 0.52 & 0.52 & \multicolumn{2}{|c|}{1.03} & & 0.76 & 0.76 & \multicolumn{2}{|c|}{1.51} & \\
\hline
\end{tabular}

Table.2 Effect of different sulphur sources at various levels on root length $(\mathrm{cm})$ of green gram

\begin{tabular}{|c|c|c|c|c|c|}
\hline \multirow[b]{3}{*}{$\begin{array}{l}\text { Sulphur } \\
\text { levels }\end{array}$} & \multicolumn{5}{|c|}{ Root length $(\mathrm{cm})$ at harvest } \\
\hline & \multicolumn{5}{|c|}{ Sulphur sources } \\
\hline & $\mathbf{S}_{1}$ & $\mathbf{S}_{2}$ & $\mathbf{S}_{\mathbf{3}}$ & $\mathbf{S}_{\mathbf{4}}$ & Mean \\
\hline $\mathbf{L}_{1}$ & 7.3 & 7.3 & 7.2 & 7.2 & 7.3 \\
\hline $\mathbf{L}_{2}$ & 11.5 & 11.0 & 10.4 & 12.1 & 11.3 \\
\hline $\mathbf{L}_{3}$ & 13.8 & 13.2 & 12.7 & 14.5 & 13.6 \\
\hline $\mathbf{L}_{4}$ & 8.9 & 8.3 & 7.7 & 9.6 & 8.61 \\
\hline \multirow[t]{2}{*}{ Mean } & 10.4 & 10.0 & 9.5 & 10.9 & \\
\hline & $\mathbf{L}$ & $\mathbf{S}$ & \multicolumn{2}{|c|}{$\mathbf{L} \times \mathbf{S}$} & \\
\hline SEd & 0.08 & 0.08 & \multicolumn{2}{|c|}{0.16} & \\
\hline $\mathrm{CD}(\mathrm{P}=0.05)$ & 0.17 & 0.17 & \multicolumn{2}{|c|}{0.33} & \\
\hline
\end{tabular}


Table.3 Effect of different sulphur sources at various levels on yield attributes of green gram

\begin{tabular}{|c|c|c|c|c|c|c|c|c|c|c|c|c|c|c|c|}
\hline \multirow{4}{*}{$\begin{array}{l}\text { Sulphur } \\
\text { levels }\end{array}$} & \multicolumn{15}{|c|}{ yield attributes } \\
\hline & \multicolumn{5}{|c|}{ No. of Pods plant ${ }^{-1}$} & \multicolumn{5}{|c|}{ No. of seeds pod ${ }^{-1}$} & \multicolumn{5}{|c|}{100 Seed weight (g) } \\
\hline & \multicolumn{5}{|c|}{ Sulphur sources } & \multicolumn{5}{|c|}{ Sulphur sources } & \multicolumn{5}{|c|}{ Sulphur sources } \\
\hline & $\mathbf{S}_{1}$ & $\mathbf{S}_{2}$ & $\mathbf{S}_{\mathbf{3}}$ & $\mathbf{S}_{4}$ & Mean & $\mathbf{S}_{1}$ & $\mathbf{S}_{2}$ & $\mathbf{S}_{\mathbf{3}}$ & $\mathbf{S}_{4}$ & Mean & $\mathbf{S}_{1}$ & $\mathbf{S}_{2}$ & $\mathbf{S}_{\mathbf{3}}$ & $\mathbf{S}_{4}$ & Mean \\
\hline $\mathbf{L}_{1}$ & 8.8 & 8.7 & 8.7 & 8.7 & 8.7 & 5.48 & 5.46 & 5.41 & 5.43 & 5.55 & 2.53 & 2.52 & 2.50 & 2.50 & 2.51 \\
\hline $\mathbf{L}_{2}$ & 13.2 & 12.4 & 11.7 & 14.0 & 12.8 & 8.45 & 7.95 & 7.44 & 7.01 & 7.71 & 3.30 & 3.13 & 3.09 & 3.36 & 3.22 \\
\hline $\mathbf{L}_{3}$ & 16.2 & 15.4 & 14.7 & 17.0 & 15.8 & 10.26 & 9.77 & 9.32 & 10.77 & 10.03 & 3.81 & 3.67 & 3.52 & 4.00 & 3.75 \\
\hline $\mathbf{L}_{4}$ & 10.3 & 9.5 & 9.4 & 11.0 & 10.0 & 6.53 & 6.15 & 6.02 & 9.50 & 7.05 & 2.89 & 2.73 & 2.68 & 2.94 & 2.81 \\
\hline \multirow[t]{2}{*}{ Mean } & 12.1 & 11.5 & 11.1 & 12.7 & & 7.68 & 7.33 & 7.05 & 8.18 & & 3.13 & 3.01 & 2.95 & 3.20 & \\
\hline & $\mathbf{L}$ & $\mathbf{S}$ & \multicolumn{2}{|c|}{$\mathbf{L} \times S$} & & $\mathbf{L}$ & $\mathbf{S}$ & \multicolumn{2}{|c|}{$L \times S$} & & $\mathbf{L}$ & $\mathbf{S}$ & \multicolumn{2}{|c|}{$L \times S$} & \\
\hline SEd & 0.14 & 0.14 & \multicolumn{2}{|c|}{0.28} & & 0.06 & 0.06 & \multicolumn{2}{|c|}{0.13} & & 0.03 & 0.03 & \multicolumn{2}{|c|}{0.06} & \\
\hline $\begin{array}{c}\mathrm{CD} \\
(\mathbf{P}=0.05)\end{array}$ & 0.29 & 0.29 & \multicolumn{2}{|c|}{0.58} & & 0.13 & 0.13 & \multicolumn{2}{|c|}{0.26} & & 0.06 & 0.06 & \multicolumn{2}{|c|}{0.11} & \\
\hline
\end{tabular}

Table.4 Effect of different sulphur sources at various levels on yield of green gram

\begin{tabular}{|c|c|c|c|c|c|c|c|c|c|c|}
\hline \multirow{3}{*}{ Sulphur levels } & \multicolumn{5}{|c|}{ Grain yield $\left(\mathrm{kg} \mathrm{ha}^{-1}\right)$} & \multicolumn{5}{|c|}{ Haulm yield $\left(\mathrm{kg} \mathrm{ha}^{-1}\right)$} \\
\hline & \multicolumn{5}{|c|}{ Sulphur sources } & \multicolumn{5}{|c|}{ Sulphur sources } \\
\hline & $\mathbf{S}_{1}$ & $\mathbf{S}_{2}$ & $\mathbf{S}_{\mathbf{3}}$ & $\mathbf{S}_{\mathbf{4}}$ & Mean & $\mathbf{S}_{1}$ & $\mathbf{S}_{2}$ & $\mathbf{S}_{\mathbf{3}}$ & $\mathbf{S}_{4}$ & Mean \\
\hline $\mathbf{L}_{1}$ & 806 & 804 & 801 & 803 & 804 & 998 & 995 & 990 & 992 & 994 \\
\hline $\mathbf{L}_{2}$ & 1035 & 987 & 946 & 1078 & 1011 & 1536 & 1466 & 1383 & 1626 & 1503 \\
\hline $\mathbf{L}_{3}$ & 1236 & 1180 & 1122 & 1297 & 1209 & 1863 & 1786 & 1702 & 1957 & 1827 \\
\hline $\mathbf{L}_{4}$ & 883 & 847 & 841 & 895 & 867 & 1226 & 1134 & 1063 & 1314 & 1184 \\
\hline \multirow[t]{2}{*}{ Mean } & 990 & 955 & 927 & 1018 & & 1406 & 1345 & 1285 & 1472 & \\
\hline & $\mathbf{L}$ & $\mathbf{S}$ & \multicolumn{2}{|c|}{ L $x$ S } & & $\mathbf{L}$ & $\mathbf{S}$ & \multicolumn{2}{|c|}{$\mathbf{L} \times \mathbf{S}$} & \\
\hline SEd & 11.8 & 11.8 & \multicolumn{2}{|c|}{23.6} & & 14.1 & 14.1 & \multicolumn{2}{|c|}{28.2} & \\
\hline $\mathrm{CD}(\mathrm{P}=\mathbf{0 . 0 5})$ & 24.1 & 24.1 & \multicolumn{2}{|c|}{48.1} & & 28.8 & 28.8 & \multicolumn{2}{|c|}{57.7} & \\
\hline
\end{tabular}




\section{References}

Dwivedi, K. N., Chandra, P., Pandey, U.C. (1996). Relative efficacy of sulphur carriers on yield of and nutrients uptake by blackgram. Journal of Indian Society of Soil Science. 44(4): 790-791.

Ghosh, G.K. and Sarkar, A.K. (2000).Efficacy of phosphogypsum as source of sulphur for chickpea (Cicer arietinum L.) in an acid soil. Indian Jouranl of Agricultural. Science. 70(6): 403- 404.

Patel, P.M., Patel, J.S., Patel, J.J. and Patel, H.P. (2010). Effect of levels and sources of sulphur on seed yield and quality of summer green gram. International Journal of Agricultural
Science. 6(1).

Pulses revolution from food to nutritional security. (2018). Crops Division, Ministry of Agriculture \& Farmers Welfare, Krishi Bhavan, New Delhi.

Singh, Y.P., Aggarwal, R.L. (1998). Effect of sulphur sources and levels on yield, nutrient uptake and quality of blackgram (Phaseolus mungo L.). Indian Journal of Agronomy.43(3): 448-452.

Saini, A.K. and Singh, R. (2017).Effect of Sulphur and Iron Fertilization on Growth and Yield of Greengram (Vigna radiate L.). International Journal of Current Microbiology and Applied Science. 6(6): 1922-1929.

\section{How to cite this article:}

Jeevitha, B., A. Rathinasamy, P.P. Mahendran, J. Prabhaharan and Prabakaran, K. 2019. Influence of Different Sulphur Sources at Various Levels on Growth and Yield of Green Gram in Alfisol of Madurai District, Tamil Nadu, India. Int.J.Curr.Microbiol.App.Sci. 8(11): 10781083. doi: https://doi.org/10.20546/ijcmas.2019.811.127 